\title{
Analysis of Knowledge and Perception of Implementation of Informed Consent in Patient Pre Operations in HVA Toeloengredjo Pare Hospital
}

\author{
Rudy Surya K. Hedo ${ }^{1}$ \\ ${ }^{1}$ Magister of Health Study \\ Program of STIKes Surya Mitra \\ Husada Kediri \\ ru4y_skh@yahoo.com
}

\begin{abstract}
Incompleteness and inaccuracy of charging informed consent in patient's pre-operation is a problem related to patient safety, professionalism, behavior, and quality culture. The research objective is to analyze the knowledge and perception of the Implementation of Informed Consent in Patients with Pre-Operations at RS HVA Toeloengredjo Pare. Design Crosssectional study using. The population is the preoperative patient at RS HVA Toeloengredjo Pare.exclusion criteria using simple random sampling technique. The independent variable of research is the knowledge and perception of the patient, and the dependent variable of the study is the completeness and accuracy of implementation preoperative patient's informed consent. Data were collected by questionnaire and a check list, then the data were analyzed using linear regression with $a<0.05$ and cross tabulation analysis. The results showed most respondents have sufficient knowledge of as many as 69 respondents $(44,8 \%)$, most respondents have the perception that quite as much as 82 respondents (53.2\%), linear regression showed that the variables significantly affect the perception of completeness informed consent $(\mathrm{p}=0.000)$ and in the knowledge variables significantly affect the accuracy of informed consent $(\mathrm{p}=0.006)$. The conclusion of this study is to increase knowledge and perception, will support the implementation of the informed consent form completeness and accuracy of informed consent.
\end{abstract}

Keyword : Informed Consent, Knowledge, Perception, PreOperation.

Copyright $@ 2018$ STIKes Surya Mitra Husada

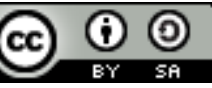

This is an open-acces article distributed under the terms of the Creative Commons Attribution-ShareAlike 4.0 International License. 


\section{INTRODUCTION}

Pre-operation begins when the decision for surgery was made and ends when the patient was transferred to the operating table. Pre-surgery there is some preparation to be prepared by the patient prior to surgery (Smeltzer, 2014). Officers in conducting the surgery is a potential or actual threat to the integrity of the person who can evoke physiological and psychological stress reaction. Officers in explain procedures and patient readiness in carrying out various operations should be assessed properly. Patients and families who have not received a full explanation will have an impact on a variety of factors that could harm the patient or attendant. The problem can be overcome by giving informed consent, namely the delivery of information containing elements: diagnosis, action will be planned, alternative procedures, the risks that arise when not carried out such an action, the patient's ability to make decisions, volunteerism of patients who gave consent (Mahmud, 2014).

Informed consent is a unilateral statement of a legitimate patient or represent that the contents of the approval of the action plan medical or dental filed by a doctor or dentist (MoH, 2008). Informed Consent in patients with pre-operation required to provide information are doctors who want to perform medical procedures because the doctor knows the patient's condition as well as matters relating to the medical procedure to be performed, but sometimes these obligations are delegated to the physician assistant or nurse but in case error in providing information by the person who delegated the responsibility still doctors who perform medical procedures. The specialist should with the orderly conduct of documenting informed consent, otherwise it could have an impact on patient safety as an indicator of hospital quality. Officers in explaining about informed consent preoperative is generally not a doctor due to various reasons, one of which is because too many patients are served so little time to consult (Kencananingtyas, Lester, \& Harjanti, 2014).

Officers in charge completeness of informed consent in patients pre-operation are still many incomplete. Research in Switzerland in 2011 found that $45 \%$ would prefer to receive informed consent through an explanation of the writing, and $80 \%$ of patients preoperative does not want informed consent to read it (Ghulam, 2011). The results of a qualitative study of nurses in the role of the filing of informed consent but has not been fully Nurses still carry out tasks that are not authority, such as providing information on a medical action (operation), request signatures on sheets of informed consent when the patient does not understand the information presented related doctor medical action to be acceptable to the patient and allowing the patient to undergo a medical action (operation) even though the doctor had not signedsheet the informed consent (Mahmud, 2014).

The results of the study in 2014 at the General Hospital of Karanganyar are Teak Husada 50 surgery onform Informed Consent not yet appear what information will be explained to the patient, not the full completeness form informed consent at charging No.KTP / SIM (100\%) and the type of information presented by the highest doctor medical action (100\%) (Kencananingtyas et al., 2014). The results showed authentication incomplete amounted to $38.10 \%$ (Yuliani \& Utami, 2013). The results showed the incompleteness informed consent reached 30-70\% (Rohmah \& Supriyanto, 2014; Sriatmi, 2015).

Results of a preliminary study on the evaluation of charging informed consent in January 2017 in RS. HVA Toeloengredjo Pare of 1608 informed consent obtained as much as $3 \%$ approver name is not filled, 3.5\% signature approver is not filled, 55\% of families witness name is not filled, $42.8 \%$ signature witness family name not be filled, $45,8 \%$ name is not filled witness officers, $22.8 \%$ signature of witness officer name was not filled, $71.1 \%$ DPJP name (Doctor patient Responsibility) is not filled, 18.4\% DPJP signature is not filled and there are a total of $33.9 \%$ informed consent is not filled out completely. Incompleteness informed consent in patient's pre-surgery at the RS. HVA Toeloengredjo Pare in January 2017 by $13 \%$.

Officers in the provision of informed consent preoperative and completeness are very important. The role of the officer giving informed consent should be able to take responsibility in helping patients and families interpret information from a variety of service providers and to provide other information necessary to take the consent(informed consent)of 
a medical procedure that is a given operating and maintaining and protecting the rights - the rights of patients, Knowledge and perceptions of patients and families to informed consent may affect the provision of informed consent was done. Incompleteness and accuracy of charging informed consent in patient's pre-operation is a problem related to patient safety, professionalism, behavior, and quality culture. Implementation of informed consent in approval is very important. Factor-charging incompleteness factor informed consent is human resources, design forms, and standard operating procedures (Sriatmi, 2015).

Incompleteness factors may result from internal factors, namely the perception of patients who received an explanation. Informed consent preoperative can be used as evidence and has the strong law contains an explanation doctor about diagnosis disease patients, the actions to be conducted by physicians, alternative measures, prognosis or consequences which may result from surgery performed specialists, but it also contains the statement that the patient has understood the explanation or information submitted and approved actions physician specialists with the signature of the patient or the patient's family as well as the signature of a specialist (Diantari, 2016). Informed consent preoperative has several functions, including the promotion of the rights of individual autonomy, protection of patients and subjects, prevent fraud or coercion, provoking the medical profession to hold introspection of self(self-security), the promotion of decisions rationally, community involvement in promoting the principle of autonomy as a social value and conduct surveillance in biomedical investigation.

What happened if the implementation of informed consent in patient's pre-operation has been done discovered the incompleteness of informed consent, it can compromise the safety of the patient during surgery or after surgery and the legal effects in case of harm to patients. Implementation of informed consent is a complete pre-operation is essential for implementing health care in hospitals. Informed Consent pre-operation is a decisive factor in fostering a sense of security and comfort for a doctor or health workers to carry out their duties in the operating room with the patient as well as recipients of health services, namely surgery. Informed consent is essential if it is associated with possible disputes between patients with a doctor or hospital in the future or if the impact will influence the medical treatment, care and surgery (Ghulam, 2011).

A variety of factors to improve the implementation of completeness and accuracy of informed consent preoperative becomes very important. Factors that lead to compliance with the implementation of informed consent in the completeness and accuracy of charging informed consent comes from organizational factors, namely the implementation of system reward and punishment that has not been balanced (Rohmah \& Supriyanto, 2014). One effort to improve the quality of health care facilities is to improve the quality of medical record services include comprehensiveness, speed and accuracy in providing information to the health care needs (Tahalele, 2016). Improvements in enhancing the completeness of informed consent preoperative is important and needs to continue efforts in monitoring and evaluating the implementation oforder in informed consent pre-operation.

The role of health professionals, especially physicians in the implementation of informed consent pre-operatives important. Incompleteness in filling informed consent preoperative to note the various factors that can be done systematic planning in tackling the problem. Incompleteness informed consent may result in adverse impacts patient. Various solutions can be applied to each individual problem that can arise from the incompleteness of informed consent preoperative was done. The solution may be in the form of policy, change the format of informed preoperative consent, or even the standard procedure in informed consent charging. Application of a good policy to be followed by the completeness of the info informed consent is complete and well too (Rahayu \& Sarwinanti, 2014). Based on the results of this study and the background of the researchers interested in studying about perception and knowledge Analysis on the Implementation of Informed Consent in Patients with Pre Operations at RS HVA Toeloengredjo Pare. 


\section{METHOD}

Design Crosssectional study using. The population is the preoperative patient at RS HVA Toeloengredjo Pare. Exclusion criteria using simple random sampling technique. The independent variable of research is the knowledge and perception of the patient, and the dependent variable of the study is the completeness and accuracy of implementation preoperative patient's informed consent. Data were collected by questionnaire and a check list, then the data were analyzed using linear regression with $a<0.05$ and cross tabulation analysis.

\section{RESULTS}

Table 1. Frequency Distribution of Knowledge in patients with pre-Operations at RS HVA on 12 October-11 November $2017(\mathrm{n}=154)$

\begin{tabular}{|c|c|c|c|}
\hline No. & Knowledge & Frequency & Percentage \\
\hline 1 & Less & 26 & 16.9 \\
\hline 2 & Enough & 69 & 44.8 \\
\hline 3 & Good & 59 & 38,3 \\
\hline & Total & 154 & 100 \\
\hline
\end{tabular}

Based on table 3 note that of the 154 respondents, most respondents have sufficient knowledge of as many as 69 respondents $(44.8 \%)$.

Table 2. Frequency Distribution of perception in patients with pre-Operations at RS HVA on 12 October-11 November $2017(\mathrm{n}=154)$

\begin{tabular}{|c|c|c|c|}
\hline No. & Perception & Frequency & Percentage \\
\hline 1 & Less than & 29 & 18.8 \\
\hline 2 & Enough & 82 & 53.2 \\
\hline 3 & Good & 43 & 27.9 \\
\hline & Total & 154 & 100 \\
\hline
\end{tabular}

Based on table 4 note that of the 154 respondents, showed that most respondents have the perception that quite as much as 82 respondents (53.2\%).

Table 3. Distribution Frequency Completeness Informed Consent in patients with preOperations at RS HVA on 12 October-11 November 2017 ( $\mathrm{n}=154)$

\begin{tabular}{|c|c|c|c|}
\hline No. & Fittings & Frequency & Percentage \\
\hline 1 & Complete & 133 & 86.4 \\
\hline 2 & Not complete & 21 & 13.6 \\
\hline & Total & 154 & 100 \\
\hline
\end{tabular}

Based on table 5 note that of the 154 respondents, showed that most informed consent respondents were complete as many as 133 respondents $(86.4 \%)$.

Table 4. Distribution Frequency Accuracy of Informed Consent in patients with preOperations at RS HVA on 12 October-11 November 2017 ( $\mathrm{n}=154)$

\begin{tabular}{clcc}
\hline No. & \multicolumn{1}{c}{ Accuracy } & Frequency & Percentage \\
\hline 1 & Accuracy & 137 & 89 \\
\hline 2 & Not Accuracy & 17 & 11 \\
\hline & Total & $\mathbf{1 5 4}$ & $\mathbf{1 0 0}$ \\
\hline
\end{tabular}


Based on table 6 known that from 154 respondents, showed that most informed consent respondents are appropriates much as 137 respondents (89\%).

Table 5. Logistic Regression Test Variables Between Knowledge and Perception With Completed Informed Consent in patients pre Operations at RS HVA on 12 October-11 November $2017(\mathrm{n}=154)$

\begin{tabular}{|c|c|c|c|c|c|c|c|c|c|}
\hline \multirow{3}{*}{ No } & \multirow{3}{*}{$\begin{array}{l}\text { Work } \\
\text { Period }\end{array}$} & \multicolumn{6}{|c|}{ Level Rank } & \multirow{3}{*}{ Total } & \multirow{3}{*}{$\%$} \\
\hline & & \multicolumn{2}{|c|}{ Eselon 3} & \multicolumn{2}{|c|}{ Eselon 4} & \multicolumn{2}{|c|}{ Kepala Instalasi } & & \\
\hline & & $\mathrm{N}$ & $\%$ & $\mathrm{~N}$ & $\%$ & $\mathrm{~N}$ & $\%$ & & \\
\hline 1 & $<10$ Years & 0 & 0 & 3 & 6,82 & 11 & 25,0 & 14 & 31,82 \\
\hline \multirow[t]{2}{*}{2} & $>10$ Years & 5 & 11,36 & 11 & 25,0 & 14 & 31,82 & 30 & 68,18 \\
\hline & & 5 & 11,36 & 14 & 31,82 & 25 & 58,82 & 44 & 100 \\
\hline
\end{tabular}

Variables in the Equation

\begin{tabular}{|c|c|c|c|c|c|c|c|c|c|c|c|}
\hline \multirow{3}{*}{ No } & \multirow{3}{*}{\multicolumn{2}{|c|}{$\begin{array}{l}\text { Work } \\
\text { Period }\end{array}$}} & \multicolumn{6}{|c|}{ Level Rank } & & \multirow{3}{*}{ Total } & \multirow{3}{*}{$\%$} \\
\hline & & & \multicolumn{2}{|c|}{ Eselon 3} & \multicolumn{2}{|c|}{ Eselon 4} & \multicolumn{2}{|c|}{ Kepala Instalasi } & & & \\
\hline & & & $\mathrm{N}$ & $\%$ & $\mathrm{~N}$ & $\%$ & $\mathrm{~N}$ & $\%$ & & & \\
\hline 1 & & 0 Years & 0 & 5 & 3 & 6,82 & 11 & 25,0 & & 14 & 31,82 \\
\hline \multirow[t]{3}{*}{2} & \multicolumn{2}{|c|}{$>10$ Years } & 5 & 11,36 & 11 & 25,0 & 14 & 31,82 & & 30 & 68,18 \\
\hline & & & 5 & 11,36 & 14 & 31,82 & 25 & 58,82 & & 44 & 100 \\
\hline & & & & & & \multirow{2}{*}{\multicolumn{2}{|c|}{$\frac{\text { Score }}{7,872}$}} & & $\mathrm{df}$ & & Sig \\
\hline \multirow{3}{*}{\multicolumn{2}{|c|}{ Step 0}} & \multicolumn{2}{|c|}{ Variables } & \multicolumn{2}{|c|}{ T Pengetahuan } & & & & \multicolumn{2}{|l|}{1,} & 005 \\
\hline & & & & \multicolumn{3}{|c|}{ T Persepsi Pasien } & 17,027 & & \multirow{2}{*}{\multicolumn{2}{|c|}{2}} & 1000 \\
\hline & & & \multicolumn{3}{|c|}{ Overall Statistics } & & 17.108 & & & & 000 \\
\hline
\end{tabular}

\section{Estimates Parameter}

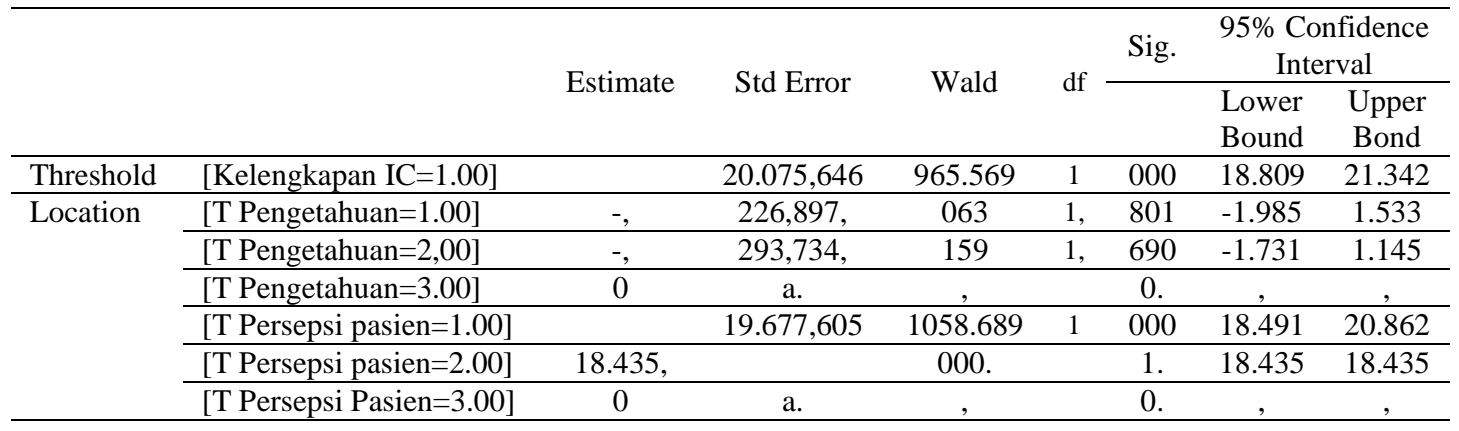

The statistical test on this new study used regression, logistics the test results listed in the table above. Statistical analysis showed that the variables in the equation obtained the value of the slope or coefficients Beta (B) of the constants (Exp (B) of 0.158, the significant value of $p$ value of wald test of 0.000 , which means that each variable give partial effect. Value B is identical to the beta coefficient on ordinary least squares (OLS) with Exp ($1.1846)=0.158$, which means that the independent variable has an influence 0.158 times the dependent variable. Statistical test results obtained total df is 2 (two), which tells us the number of variables independent 2 (two).

Statistical test results the next stage in the second table shows that $\mathrm{p}<\mathrm{a}$ with a value $\leq$ 0.05 , as seen in the Overall statistics with significance value of (p) 0.000 , which means that there are variables that affect the completeness IC both knowledge and perception of respondents. When viewed value (p) for each independent variable that is variable knowledge (p) of 0.005 and a variable perception of respondents about IC (p) of 0.000 . 
Table 6. Logistic Regression Test Variables Between Knowledge and Perceptions of the Appropriateness of informed consent in patients with pre Operations at RS HVA on 12 October-11 November $2017(\mathrm{n}=154)$

Variables in the Equation

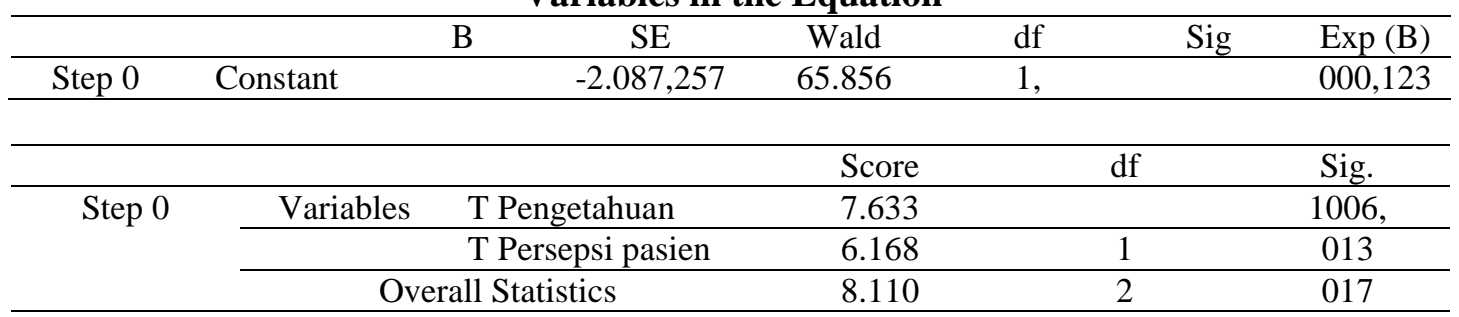

\section{Estimates Parameter}

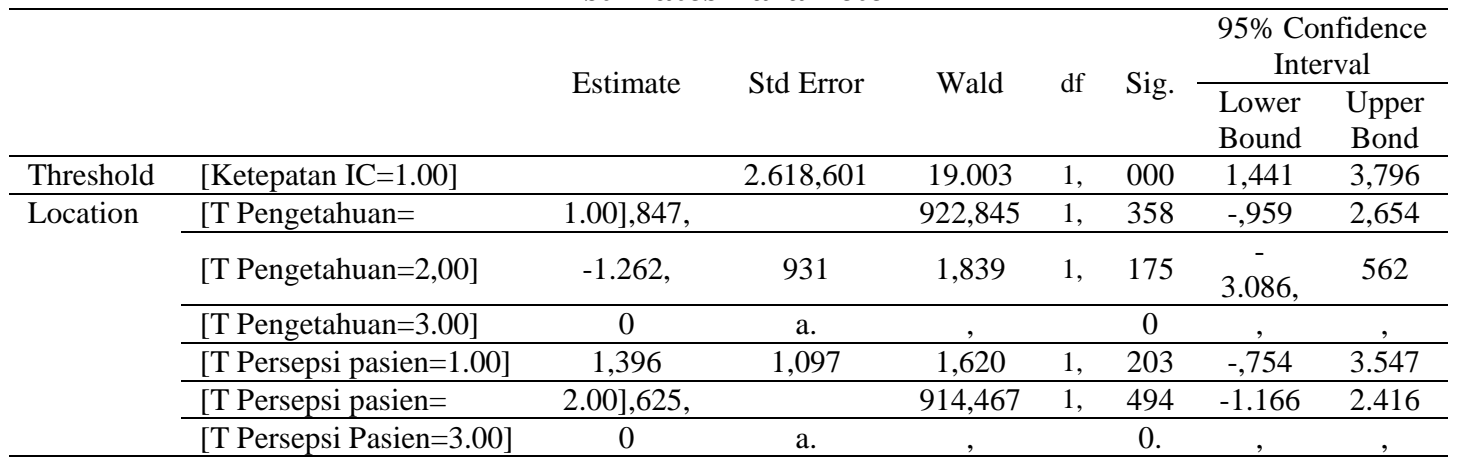

Link function: Logit.

This parameter is set to zero Because it is redundant.

The statistical test on this new study used regression, logistics the test results listed in the table above. Statistical analysis showed that the variables in the equation obtained the value of the slope or coefficients Beta (B) of the constants (Exp (B) of 0.124, the significant value of $p$ value of wald test of 0.000 , which means that each variable give partial effect. Value B is identical to the beta coefficient on ordinary least squares (OLS) with Exp (-2.087) $=0.124$, which means that the independent variable has an influence 0.127 times the dependent variable. Statistical test results obtained total df is 2 (two), which means the number of independent variables exist 2 (two).

Statistical test results the next stage in the second table shows that $\mathrm{p} \leq \mathrm{a}$ with a value $\leq$ 0.05 , as seen in the Overall statistics with significance value of (p) 0,050 , which means that there are variables that affect the accuracy of IC good knowledge and perception of respondents. When viewed value (p) for each independent variable that is variable knowledge (p) of 0.006 and a variable perception of respondents comppled IC (p) of 0,016.

\section{DISCUSSION}

Based on the results showed that that variables in the equation values obtained slope or coefficient Beta (B) of the constants (Exp (B) of 0.158 , the significant value $p$ value of wald testof 0.000 , which means that each variable give partial effect. Value B is identical to the beta coefficient on ordinary least squares $(\mathrm{OLS})$ with $\operatorname{Exp}(-1.1846)=0.158$, which means that the independent variable has an influence 0.158 times the dependent variable. Statistical test results obtained total df is 2 (two) which tells us the number of independent variables there are 2 (two). And found that $\mathrm{p}<\mathrm{a}$ with a value $\leq 0.05$, as seen in the Overall Statistics with significance value of (p) 0.000 , which means that there are variables that affect the completeness IC good knowledge and perception of respondents. When viewed value (p) 
for each independent variable that is variable knowledge (p) of 0.005 and a variable perception of respondents about IC (p) was 0,000

Based on research results indicate that the completeness of the IC depends on knowledge and perception of respondents. Based on the results that most informed consent fully and accurately as many as 127 informed consent respondents (82\%). The results also showed that there were 11 informed consent of respondents (7.1\%) with informed consent incomplete and imprecise.

The medical record is a file that contains records and documents of identity, history taking, diagnosis treatment, examination, treatment, action, and other services provided to patients in health care facilities include patient registration that starts from a place of admission, then responsible for collecting, analyzing, processing, and ensure the completeness of the medical record file of the unit outpatient, inpatient units, emergency rooms, and other supporting units (Lopez, 2010).

Informed consent is an approach to the truth and patient involvement in decisions about their treatment. Often the best approach to obtain an informed consent is that doctors will propose or perform procedures to give a detailed explanation in addition to asking patients to read the form (Komalawati, 2002). Medical Record is the who, what, where, and how to care for a patient in the hospital, to complement the medical record must have enough data is written in a series of activities in order to produce a diagnosis, assurance, treatment, and outcomes. The medical record is a testimony both written and recorded on the patient's identity, anamneses determination of the physical laboratory, diagnosis of all services and medical action that is given to the patient and the treatment of both the inpatient, outpatient and getting emergency services (Erfavira, 2012; Giyana 2012; Rustiyanto 2009; Yanuari, 2012).

Objectives of Informed Consent according Guwandi J. (2007) is to protect the patient against any medical action undertaken without the knowledge of the patients is to give legal protection to the doctor to the effect that no unforeseen and negative, for example against the risk of treatment that cannot be avoided even if the doctor has seeking a way as possible and act very cautiously and carefully. Informed Consent has a purpose, namely to study (patients are asked to become research subjects), look for the diagnosis, treatment, protecting patients against all medical action undertaken without the knowledge of the patient, provide legal protection for doctors against due to unforeseen and negative, for example against risk of treatment that cannot be avoided even if the doctor was seeking as much as possible and move very cautiously and carefully.

Perception and a good knowledge directly proportional to the completeness of informed pre Operations consent. It is an interpretation that perception and knowledge about informed consent is obtained capable of affecting the completeness of informed consent to do the clerk this can be influenced by the stimulus or process that occurs when the giver of the current explanation given informed consent, in accordance with the disclosed Sugihartono, et al (2007), which suggests that the perception is the brain's ability to translate the stimulus or process for translating stimulus into the human sensory organs. Perception and knowledge affecting the completeness of informed consent may also be due to the attitude and focus of attention and information of the respondents in the provision of informed consent is ongoing so that the process of reciprocal officer in giving informed consent are complete according to the type of information provided, it is supported by Miftah Toha (2003), which states that the factors that influence a person's perception is the attitude and attention (focus). A positive perception of the information provided personnel to support completeness of information on informed a givenconsent.

Based on the results of the study of perception and a good knowledge of a supporter in the completeness of the IC. A complete IC is also the administrative process, the safety of patients get services were also obtained. IC are very important in the process of documentation, administration and patient safety. Completeness IC preoperative become an important capital in the action before the surgery. The explanation given by clear, precise, and can be accepted will increase the trust of patients to health workers. Knowledge and perceptions affect significantly the completeness of the IC, and this must be improved 
through health education about the importance of information before getting health care and every decision of the patient will be honored as legal ethics that authority as patients in obtaining health services and medical.

Researchers found IC completeness variables that affect both knowledge and perception of respondents, is the picture of the implementation of the management condition in hospital, so that management needs to continue improving the quality of service and charging IC in hospitals, especially in patients with pre-surgery. This will increase customer confidence in the use of hospital services in particular-surgery patients.

Based on the results of the study showed that the variables in the equation obtained the value of the slope or coefficients Beta (B) of the constants (Exp (B) of 0.124, the significant value of $p$ value of wald test of 0.000 , which means that each variable give partial effect. Value B is identical to the beta coefficient on ordinary least squares (OLS) with Exp (-2.087) $=0.124$, which means that the independent variable has an influence 0.127 times the dependent variable. Statistical test results obtained total df is 2 (two), which means the number of independent variables exist 2 (two). Statistical test results showed that $\mathrm{p} \leq \mathrm{a}$ with a value $\leq 0.05$, as seen in the Overall statistics with significance value of $(p) 0,050$, which means that there are variables that affect the accuracy of IC both knowledge and perception of respondents. when seen the value of $(p)$ for each independent variable that is variable knowledge (p) of 0.006 and a variable perception of respondents about IC (p) 0,01 6 .

Based on the research that all independent variables affect the dependent variable .. The results showed that the informed consent incomplete and imprecise as much as $6.9 \%$. Information informed consent given to patients is very important preoperative information is data that has been processed into a form that is meaningful to the recipient and useful in making decisions. Relations with the communication, information is one element of communication is the process of delivering information on the "communicator" to "communicant" (Notoatmodjo, 2010). Ease of obtaining information will accelerate a person to acquire new knowledge (Mubarak, et al., 2007).

Good medical record can reflect the quality of health care provided. Quality medical records are also needed for medical evaluation and audit preparation to medical services retrospective review of medical records. Without the fulfillment of the terms of the quality of these medical records, the medical personnel and the hospital would be difficult to defend themselves in court when there is a malpractice suit of patients (Lopez, 2010). Patients and their families should be encouraged to ask questions according to his will, and must be answered honestly and clearly. The purpose of this oral explanation is to ensure that if a patient sign a form that really has got the full information (Komalawati, 2002).

Research has been conducted by Sirani (2015) found that the incompleteness figure reached $70 \%$ which is not exhaustive and is only $30 \%$ complete. Appropriateness of informed consent is determined by the timeliness of the provision, the competent authorities deliver, and the accuracy of the information on the type of sheet. informed consent Approval granted by competent individuals. In terms of age, a person is considered competent when aged 18 years or older or have never been married. While children aged 16 years or older but not yet 18 years of age can make certain medical consent that are not at high risk if they can demonstrate competence in making decisions. Good medical record can reflect the quality of health care provided. Quality medical records are also needed for medical evaluation and audit preparation that medical services retrospective review of medical records. Without the fulfillment of the terms of the quality of these medical records, the medical personnel and the hospital would be difficult to defend themselves in court when there is a malpractice suit from a patient. Good quality medical records are medical records which meet the quality indicators of medical records (Lopez, 2010) that is stuffing resumes medical record completeness, accuracy, timely, compliance with legal requirements.

A good knowledge of the informed consent then the person will be more responsive and simulating a person to want to get the fullest information before surgery. A good knowledge affects the accuracy of giving informed consent for influencing attitudes in accordance with knowledge. A national standard formulation, education is a conscious effort 
to prepare students through guidance, instruction, and / or training for its role in the future (Hamalik, 2011). A good knowledge will cause accuracy in giving informed consent.

Based on the description above, the researchers found the variables that affect the accuracy of IC both knowledge and perception of respondents. Knowledge and perception variables jointly affect the accuracy of informed consent. But if you look one by one variable obtained that knowledge variable affecting the completeness variable IC. Information is a collection of data that is formed to provide the knowledge or can change the perception. With that knowledge and correct information about the health of the IC can support the accuracy of the IC administration. The accuracy of the IC Award in the form of punctuality given and the person who gives the IC. Is the risk that the information given is wrong, and officers who provide pre-IC operation is not medical personnel who will carry out an act of surgery.

\section{REFERENCES}

Barbara, C. L. (2012). Perawatan Medikal Bedah (Suatu Pendekatan Proses Keperawatan. Bandung: IAPK.

Diantari, M. (2016). Tinjauan Pelaksanaan Pengisian Informed Consent: Tindakan Operasi di Rumah Sakit Ummum Pusat H. Adam Malik Medan Tahun 2016. Apikes Imelda Medan.

Erfavira, A. (2012). Perbedaan Kelengkapan Pengisian Rekam Medis Antara Instansi Rawat Jalan Dan Instalasi Rawat Darurat di Poli Bedah RSUP Dr. Kariadi. Semarang.

Ghulam, A. T. (2011). Patients' Satisfaction With the Preoperative Informed Consent Procedure: A Multicenter Questionnaire Survey in Switzerland. Mayo Clinic Proceeding, 81(3), 307-312.

Giyana, F. (2012). Analisis Sistem Pengelolaan Rekam Medis Rawat Inap Rumah Sakit Daerah Kota Semarang. Jurnal Kesehatan Masyarakat, 1(2), 48.

Hamalik. (2011). Manajemen Pengembangan Kurikulum. Bandung: PT Remaja Rosdakarya.

Herfiyant, L. (2015). Kelengkapan Informed Consent Tindakan Bedah Menunjang Akreditasi JCI Standar HPK 6 Pasien Orthopedi. Jurnal Manajemen Informasi Kesehatan Indonesia, $3(2), 1$.

Ihsan. (2008). Dasar-Dasar Kependidikan. Jakarta: Rineka Cipta.

Jong, D. (2013). Buku Ajar Ilmu Bedah. Jakarta: EGC.

Kemenkes. (2008). No. 290/ MENKES/ PER/ III/ 2008. Jakarta: Kementerian Kesehatan RI.

Kencananingtyas, S. A., Lestari, T., \& Harjanti. (2014). Pelaksanaan Pemberian Informed Consent dan Kelengkapan Informasi di RSU Jati Husada Karanganyar. Apikes Mitra Husada, $1(1), 86-91$.

Komalawati, V. (2002). Peranan Informed Consent dalam Transaksi Terapeutik (Persetujuan Dalam Hubungan Dokter dan Pasien) Suatu Tinjauan Yuridis. Bandung: Citra Aditya Bakti.

Long, B. (2013). Perawatan Medikal Bedah. Bandung: IAPK.

Lubis. (2010). Pengantar Psikologi Dalam Keperawatan. Jakarta: Kencana Prenada Media Group. 
Mahmud. (2014). Peran Perawat dalam Informed Consent pre Operasi di Ruang Bedah Rumah Sakit Umum Pemangkat Kalimantan Barat. Undip.

Mubarak. (2007). Promosi Kesehatan Sebuah Pengantar Proses Belajar Mengajar dalam Pendidikan. Yogyakarta: Graha Ilmu.

Notoatmodjo. (2010). Promosi Kesehatan dan Ilmu Perilaku. Jakarta: Rineka Cipta.

Potter, P. A. (2014). Essentials for Nursing Practice. United States of America: Elsevier Health Sciences.

Rahayu, S., \& Sarwinanti. (2014). Hubungan Penerapan Kebijakan dengan Kelengkapan DOkumentasi Informed COnsent di Bangsal Cendana RSUP Dr. Sarjito Yogyakarta. Stikes Aisyiyah Yogyakarta, 1(1), 1.

Rohmah, M., \& Supriyanto, S. (2014). Kepatuhan Petugas Kesehatan dalam Kelengkapan Penisian Informed Consent. Jurnal Administrasi Kesehatan Indonesia, 2(2), 128-137.

Rustiyanto, E. (2009). Etika Profesi: Perekam Medis Informasi Kesehatan. Yogyakarta: Sudra.

Smeltzer, S. (2014). Textbook of Medical Surgical Nursing (8th ed.). United Kingdom: Lippincott Williams.

Sriatmi, E. (2015). Analisis Faktor-Faktor Ketidaklengkapan Formulir Informec Consented di Rumah Sakit Ungaran. PSI UDINUS, 1(1), 1.

Sugiyono. (2013). Metode Penelitian Kuantitatif, Kualitatif dan R\&D. Bandung: Alfabeta.

Tahalele. (2016). Hubungan antara faktor Personil Perencanaan Pulang dengan Kelengkapan Resume Medis Pasien di Rumah Skait Umum Daerah Maba Kabupaten Halmahera Timur. Ejournal Keperawatan, 4(1), 1-8.

Yanuari, R. (2012). Perbedaan kelengkapan Pengisian Rekam Medis Antara Dokter Umum dan Dokter Spesialis Pada Praktek Swasta mandiri di kecamatan Semarang Selatan Kota Semarang. Universitas Diponegoro. Semarang.

Yuliani, N., \& Utami, T. (2013). Kelengkapan Data Autentifikasi Dokter pada Pasien Rawat Inap Bedah di RS Nirmala Suri Sukoharjo. Infokes, 3(1), 1-9. 